\title{
STRATEGI PENGEMBANGAN DESA WISATA OSING DALAM UPAYA PEMULIHAN EKONOMI PADA MASA PANDEMI COVID-19
}

\author{
Adhinda Dewi Agustine ${ }^{*}$, Akbar Pandu Dwinugraha ${ }^{2}$ \\ 1,2 Fakultas Ilmu Sosial dan Ilmu Politik, Universitas Merdeka Malang. \\ *)Korespondensi : adhinda.dewi@unmer.ac.id
}

Article Histori: Accepted: 29/9/2021

Review: 4/10/2021

Publish: 31/10/2021

\section{Abstract}

This study tries to find a strategy for developing the Osing Tourism Village as an effort to recover the economy during the Covid-19 pandemic. This type of research is a combination (mix method) used in this study. The research location is Osing Tourism Village in Banyuwangi Regency with the target group being a tourism-aware group that manages Osing Tourism Village. The time for collecting research data is in the period June-September 2021. Based on the results of the data obtained, four strategies are produced that can be used for the development of the Osing tourism village. First, optimizing the improvement of the image and branding of the Osing Indigenous Tourism Village so that it remains the choice of tourist destination in the New Normal era. Second, increasing the capacity of human resources for tourism actors in the use of digital technology facilities to support tourism during the Covid-19 pandemic. Third, changing the trend of tourism into technology-based tourism in terms of product marketing and tourism management. To bring the Osing tourism village to life through product innovations that are preferred by consumers with attractive and contemporary packaging models. Fourth, collaborate with the private sector and local governments in providing facilities and infrastructure to support tourism activities during the Covid-19 pandemic.

Keyword: Strategy, Tourist Village, Economic Recovery, Covid-19

\section{PENDAHULUAN}

Pariwisata merupakan salah satu sektor terpenting di dunia dan juga di Indonesia, yang mana pariwisata saat ini banyak mengalami perkembangan dengan pengaruh berbagai factor. Bidang pariwisata juga mempunyai peranan dalam membangun perekonomian masyarakat khususnya di daerah sekitar wilayah destinasi wisata itu sendiri. Dalam Undang-Undang Nomor 10 Tahun 2009 tentang Kepariwisataan disebutkan bahwa, Pembangunan Kepariwisataan diperlukan untuk mendorong pemerataan kesempatan berusaha danmemperolehmanfaatserta mampu menghadapi tantangan perubahan kehidupan lokal, nasional, dan global. Dengan memperhatikan dari tujuan pembangunan pariwisata tersebut maka dapat meningkatkan kesejahteraan masyarakat; menghapus kemiskinan; mengatasi pengangguran; melestarikan alam, lingkungan dan sumber daya; melestarikan dan memajukan kebudayaan; mengangkat citra bangsa; memupuk rasa cinta tanah air; memperkokoh jati diri dan kesatuan bangsa; serta mempererat persahabatan antar bangsa.

Pariwisata juga merupakan sumber nilai strategis yang berasal dari inspirasi budaya lokal yang dikembangkan dengan potensi lokalitasnya menjadi pengembangan kegiatan kepariwisataan. Sebagai bentuk upaya pelestarian kearifan local yang tidak melupakan nilai dan spirit 
budayanya maka diperlukan pengembangan dan pengelolaan secara bersama-sama antara pemerintah daerah dengan masyarakat sekitar. Sebagai sebuah perwujudan kerja keras dalam melestarikan dan memegang erat budaya yang menjadi sumber positif dalam peningkatan perekonomian masyarakat yang terjalin dengan baik.

Sebagai perwujudan dalam hal tersebut pengembangan wisata daerah semestinya dilakukan dengan merata dan berfokus pada pembangunan ekonomi kerakyatan yaitu pemberdayaan masyarakat yang mengutamakan peningkatan ekonomi rakyat (Baswir, 1995). Beberapa pakar menyatakan pentingnya pembangunan dimulai dari masyarakat setempat atau warga lokal itu sendiri. Sebagaimana diketahui bersama adanya permasalahan sosial yang cukup serius terjadi sejak awal tahun 2020 yaitu munculnya pandemi virus Covid -19 yang melanda setiap negara termasuk di Indonesia. Munculnya kasus pandemi Covid-19 memberikan dampak yang signifikan terhadap social ekonomi di Indonesia terutama sektor pariwisata. Ferdiansyah,dkk (2020) menyatakan pandemi Covid-19 telah menyebabkan kondisi krisisi di desa wisata dan sector pariwisata secara umum sehingga diperlukan langkah-langkah strategis dalam meminimalkan resiko dan memulihkan kondisi layanan wisata. Keberhasilan pengembangan desa wisata kedepannya akan dapat mempercepat proses pemulihan peningkatan ekonomi daerah pada masa pandemi Covid-19.

Dalam polemik pandemi Covid-19 ini juga menjadikan tantangan tersendiri bagi pemerintah daerah, stakeholder dan masyarakat sekitar. Sehingga diperlukan adanya strategi pengembangan pariwisata yang lebih efektif atau kebijakan yang tepat untuk diterapkan agar kegiatan wisata tetap bisa dijalankan di masa pademi Covid-19, yang tentuya dengan menjalankan aturan-aturan yang berlaku.. Sebagaimana yang terjadi di daerah Kabupaten Banyuwangi, yang saat ini menjadi salah satu primadona dan pilihan yang menarik bagi wisatawan domestik maupun mancanegara.
Kabupaten Banyuwangi yang dikenal dengan julukan The Sunrise ofJawainimenyajikan berbagaispot wisata berkelas dunia yang berada di ujung tertimur Pulau Jawa. Memiliki Banyak alternatif destinasi pariwisata yang berbeda dari tempat wisata lainnya, memberi ketertarikan tersendiri terhadap wisatawan untuk berkunjung dan memiliki berbagai pesona destinasi wisata untuk memikat hati para pelancong lokal maupun wisatawan mancanegara. Dengan mengusung konsep ekoturisme Banyuwangi berhasil mengembangkan pariwisata yang berwawasn lingkungan dengan mengutamakan aspek konservasi alam, pemberdayaan social budaya dan ekonomi masyarakat lokal.

Tidak hanya alam yang menjadi daya Tarik Banyuwangi, tetapi kebudayaan asli kota pun berhasil mencuri perhatian pengunjung. Oleh karena itu untuk menjaga kelestarian kebudayaan Banyuwangi, Pemerintah Kabupaten menetapkan Desa Wisata Osing sebagai cagar budaya serta mengembangkannya menjadi desa wisata. Desa Wisata Osing ini memiliki potensi alam yang menarik, tinggi tradisi, banyak kesenian, bermacam kuliner khas daerah dan yang paling unik adalah memiliki bahasa daerah sendiri yaitu bahasa osing. Seluruh penduduk Desa Kemiren merupakan Suku Osing (Suku asli Banyuwangi) (Syaiful et al., 2015) yang sangat menghormati dan menghargai budaya dalam segala suasana. Disamping itu masyarakat adat osing mempunyai ciri- ciri umum yaitu menggunakan bahasa osing pada keseharian, memiliki danyang desa (buyut) di desanya, masih menjalankan ritual bersih desa, dan menyakini kepercayaan yang diwarisi oleh leluhurnya.

Adanya keberagaman potensi dan daya tarik yang dimiliki oleh Desa Wisata Osing ini menjadi unsur utama dalam pengembangan pariwisata dan menjadikan desa ini merupakan objek wisata berbasis budaya yang melestarikan nilainilai adat serta kehidupan sosial kultural dengan menawarkan berbagai keunikan budaya yang dikemas dalam bentuk festival ataupun paket wisata 
dengan beberapa agenda atau kegiatan festival desa wisata osing.

Munculnya masa pandemi Covid-19 mendorong desa wisata osing ini untuk dapat beradapatasi dengan kebiasaan baru dalam menjalankan kegiatan kepariwisataan dan diperlukan peran aktif masyarakat lokal dalam memperbaiki mutu sumberdaya manusia, produk yang ditawarkan, serta pengaturan dan pengelolaan manajamen desa wisata kedepannya. Sehingga kesejahteraan masyarakat daerah pada tatanan melestarikan alam dan nilai-nilai sosial budaya dapat ditingkatkan.

\section{KAJIAN LITERATUR}

Strategi menurut David (2011:18-19) adalah sarana bersama dengan tujuan jangka panjang yang hendak dicapai. Strategi menjadi hal penting dalam pengembangan visi misi untuk mencapai sasaran atau jtujuan yang telah ditetapkan. Sedangkan menurut Anthony, Parrrewe dan Kacmar (1999) strategi didefinisikan sebagai formulasi misi dan tujuan organisasi, termasuk didalamnya adalah rencana aksi (actions plans) untuk mencapai tujuan tersebut secara eksplisit dengan mempertimbangkan kondisi persaingan dan pengaru-pengaruh kekuatan di luar organisasi yang secara langsung atau tidak berpengaruh terhadap kelangsungan organisasi (Nainggolan, 208).

$$
\text { Menurut Kamus Besar Bahasa }
$$

Indonesia, strategi adalah ilmu dan seni yang menggunakan sumber daya bangsa untuk melaksanakan kebijaksaan tertentu dalam perang dan damai. Selain itu pengertian dari strategi menurut para ahli yang lain seperti Quinn (1990:10) menyebutkan bahwa strategi adalah pola atau rencana yang mengintegrasikan tujuan, kebijakan dan aksi utama dalam hubungan yang kohesif, dimana sebuah strategi yang baik akan dapat membantu organisasi dalam mengalokasikan sumber daya yang dimiliki dalam bentuk unik berbasis kompetensi internal serta kemampuan mengantisipasi lingkungan.
Marus dalam Ummar (2002:31) menerangkan strategi sebagai suatu proses penentuan rencana para pemimpin puncak yangberfokus pada tujuan jangka panjang organisasi, disetai penyusunan suatu cara atau upaya bagaimana agar tujuan tersebut dapat dicapai. Strategi didefinisikan khusus sebagai tindakan yang bersifat incremental (senantiasa meningkat) dan terus-menerus , serta dilakukan berdasarkan sudut pandang tentang apa yang diharapkan oleh para pelanggan masa depan.

Lebih lanjut menurut Maijd (2013), mengemukakan bahwa strategi adalah pola umum tentang keputusan atau tindakan (strategies are realized as patterns in stream of decisions or actions). Dalam dunia pendidikan, Sutarjo (2014) menyatakan bahwa strategi diartikan sebagai a plan, method,or series of activities designed to achieved a particular educational goal, strategi diartikan perencanaan yang berisi tentang serangkaian kegiatan yang didesain untuk mencapai tujuan pendidikan tertentu

Desa wisata adalah sebuah kawasan pedesaan yang memiliki beberapa karakteristik khusus untuk menjadi daerah tujuan wisata. Hadiwijoyo (2012) menyatakan bahwa desa wisata adalah suatu kawasan pedesaan yang menawarkan keseluruhan suasana yang mencerminkan kehidupan sosial, ekonomi, adatistiadat,keseharian, memilikiarsitektur bangunan dan struktur tata ruang desa yang khas, atau kegiatan perekonomian yang unik dan menarik serta mempunyai potensi untuk dikembangkanna berbagai komponen kepariwisataan, misalnya atraksi, akomodasi, makanan-minuman dan kebutuhan wisata lainya. Sedangkan Chusmeru (2010) mendefinisikan desa wisata sebagai bentuk integrasi antra atraksi, akomodasi dan fasilitas pendukung yang disajikan dalam suatu struktur kehidupan masyarakat yang menyatu dengan tata cara dan tradisi yang berlaku.

\section{METODE PENELITIAN}

Jenis penelitian kombinasi (mix methode) digunakan dalam penelitian ini. Jenis ini menggabungkan pendekatan kualitatif dan kuantitatif (Creswell: 2009). 
Lokasi penelitian adalah Desa Wisata Osing di Kabupaten Banyuwangi dengan kelompok sasarannya adalah kelompok sadar wisata yang mengelola Desa Wisata Osing. Waktu pengumpulan data penelitian adalah pada periode bulan Juni September 2021. Teknik pengumpulan data penelitian menggunakan kuesioner elektronik terbuka. Analisis data dibagi menjadi beberapa tahap. Pertama, data responden yang masuk akan dilakukan pengelompokkan (Grouping) kedalam kalimat faktor eksternal maupun internal berdasarkan kesamaan jenis jawaban responden. Hal tersebut dilakukan hingga seluruh data jawaban responden tidak tersisa dan terkelompokkan secara keseluruhan. Kedua, hasil grouping kemudian dilakukan pembobotan berdasarkan seberapa banyak responden yang menjawab dengan jawaban sejenis. Selain itu pembobotan juga dilakukan dengan pendekatan expert judgement berdasarkan hasil diskusi dan wawancara secara online antara peneliti bersama dengan informan kunci. Ketiga, dilakukan identifikasi nilai $\mathrm{x}$ dan $\mathrm{y}$ berdasarkan hasil pembototan dan perhitungan skoring untuk masing masing isian analisis faktor eksternal maupun internal untuk menghasilkan matrik analisis, diagram maupun rekomendasi strategi melalui SWOT.

\section{HASIL DAN PEMBAHASAN}

Hasil pertama dalam Analisis Faktor lingkungan internal adalah menjelaskan dua bagian dari SWOT yaitu strenght (kekuatan) dan weakneses (kelemahan). Pada bagian ini dijelaskan sejauh mana kekuatan serta kelemahan yang dimiliki dapat dimanfaatkan. Kondisi tersebut disajikan melalui tabel berikut:

Tabel 1. Matrik Internal Factor Analysis Summary (IFAS)

\begin{tabular}{|c|c|c|c|c|}
\hline No. & Faktor Strategi Internal & $\begin{array}{c}\text { Bobot } \\
\text { (Weighted })\end{array}$ & $\begin{array}{c}\text { Peringkat } \\
\text { (Rating) }\end{array}$ & Skor Bobot \\
\hline \multicolumn{5}{|c|}{ Kekuatan (Strenght) } \\
\hline 1. & $\begin{array}{l}\text { Kekayaan tradisi, seni dan budaya Using } \\
\text { telah bertahan dan terintegrasi dalam gerak } \\
\text { hidup masyarakat Kemiren. }\end{array}$ & 0,1 & 6 & 0,60 \\
\hline 2. & $\begin{array}{l}\text { Tingginya Partisipasi masyarakat Kemiren } \\
\text { terhadap aktifitas tradisi, seni dan budaya } \\
\text { Osing. }\end{array}$ & 0,08 & 3 & 0,24 \\
\hline 3. & $\begin{array}{l}\text { Tingginya motivasi ekonomi masyarakat } \\
\text { Kemiren terkait pengembangan wisata } \\
\text { berbasis partisipasi masyarakat }\end{array}$ & 0,065 & 3 & 0,20 \\
\hline 4 & $\begin{array}{l}\text { Keterampilan masyarakat Kemiren dalam } \\
\text { pembuatan produk kerajinan berbahan } \\
\text { lokal }\end{array}$ & 0,05 & 4 & 0,20 \\
\hline 5 & $\begin{array}{l}\text { Keberadaan tokoh-tokoh berpengaruh di } \\
\text { Kemiren }\end{array}$ & 0,2 & 5 & 1 \\
\hline & Total Skor Strenght & 0,495 & & 2,24 \\
\hline \multicolumn{5}{|c|}{ Kelemahan (weakneses) } \\
\hline 1 & $\begin{array}{l}\text { Lemahnya daya saing dan manajemen } \\
\text { usaha dalam produk-produk kerajinan/ } \\
\text { souvenir sebagai penunjang industri } \\
\text { pariwisata desa. }\end{array}$ & 0,05 & 3 & 0,15 \\
\hline 2 & $\begin{array}{l}\text { Masih rendahnya Sumber daya manusia } \\
\text { bidang pariwisata. }\end{array}$ & 0,15 & 6 & 0,75 \\
\hline 3 & $\begin{array}{l}\text { Lemahnya branding Image sebagai desa } \\
\text { wisata berbasis adat dan budaya }\end{array}$ & 0,1 & 3 & 0,3 \\
\hline
\end{tabular}




\begin{tabular}{clccc}
\hline No. & \multicolumn{1}{c}{ Faktor Strategi Internal } & $\begin{array}{c}\text { Bobot } \\
(\text { Weighted })\end{array}$ & $\begin{array}{c}\text { Peringkat } \\
\text { (Rating) }\end{array}$ & Skor Bobot \\
\hline 4 & $\begin{array}{l}\text { Masih rendahnya penguasaan dan adopsi } \\
\text { terhadap digitalisasi pada SDM pariwisata }\end{array}$ & 0,125 & 6 & 0,75 \\
& $\begin{array}{l}\text { Desa Wisata Adat Osing } \\
\text { Informasi tentang ragam daya tarik wisata } \\
\text { yang belum memadai }\end{array}$ & 0,08 & 3 & 0,24 \\
\hline Total Skor Weakneses & 0,505 & 2,34 \\
\hline & 1 & 4,58 \\
\hline
\end{tabular}

Hasil kedua dalam analisis faktor lingkungan eksternal ditujukan guna melakukan analisis terhadap ancaman dan peluang yang dimiliki. Selanjutnya disajikan melalui tabel berikut.

Tabel 2. Matrik External Factor Analysis Summary (EFAS)

No.

Faktor Strategi External

Bobot

(Weighted)

Peluang (Opportunity)

1. Desa Kemiren memiliki lokasi strategis dimana menjadi jalur penghubung antara

0,1

Peringkat

Skor Bobot kawasan wisata Kawah Ijen dengan Wisata Pemandian Tamansuruh dan Perkebunan Kalibendo serta posisi Kemiren hanya berjarak $5 \mathrm{~km}$ dari pusat kota Banyuwangi

2. Hadirnya Perguruan Tinggi dengan Lembaga Penelitian dan Pengabdian kepada Masyarakat sebagai mitra masyarakat dan pemerintah

3. Dukungan Pemerintah Kabupaten 0,05

4 Berkembangnya teknologi informasi sebagai media untuk memasarkan program-program wisata di Kemiren

5 Belum banyak desa Kompetitor dengan khasanah kebudayaan dan adat yang lebih menarik

\begin{tabular}{|c|c|c|c|c|}
\hline & Total Skor Opportunity & 0,4 & & 0,95 \\
\hline \multicolumn{5}{|c|}{ Ancaman (Treats) } \\
\hline 1. & $\begin{array}{l}\text { Kondisi Pandemi Covid-19 menyebabkan } \\
\text { penurunan jumlah wisatawan }\end{array}$ & 0,2 & 4 & 0,8 \\
\hline 2. & $\begin{array}{l}\text { Kondisi social distancing mengakibatkan } \\
\text { pembatasan kegiatan masyarakat terutama } \\
\text { dalam pengelolaan kepariwisataan }\end{array}$ & 0,2 & 4 & 0,8 \\
\hline 3. & $\begin{array}{l}\text { Terjadinya Kecemburuan antar desa yang } \\
\text { berhubungan dengan pengembangan } \\
\text { wisata }\end{array}$ & 0,1 & 2 & 0,1 \\
\hline 4. & $\begin{array}{l}\text { Sarana moda transportasi (menuju) desa } \\
\text { yang kurang memadai }\end{array}$ & 0,05 & 1 & 0,05 \\
\hline 5. & $\begin{array}{l}\text { Koordinasi dalam manajemen/pengelolaan } \\
\text { kegiatan wisata di antara para stakeholders } \\
\text { belum berjalan secara baik }\end{array}$ & 0,1 & 2 & 0,2 \\
\hline \multirow{2}{*}{\multicolumn{2}{|c|}{ Total Skor Treats }} & 0,6 & & 1,5 \\
\hline & & 1 & & 2,90 \\
\hline
\end{tabular}


Berdasarkan hasil penentuan bobot pada masingmasing matriks IFAS dan EFAS, selanjutnya dilakukan indentifikasi terhadap sumbu $\mathrm{x}$ dan $\mathrm{y}$ dengan cara mencari selisih antara skor kekuatan dan kelemahan serta selisih antara skor peluang dan ancaman maka diperoleh koordinat dalam kuadran SWOT sebagai penggambaran posisi Desa Adat Kemiren dalam upaya pemulihan dalam masa pandemi Covid-19 yang disajikan melalui gambar berikut.

Gambar 1. Kuadran analisis SWOT

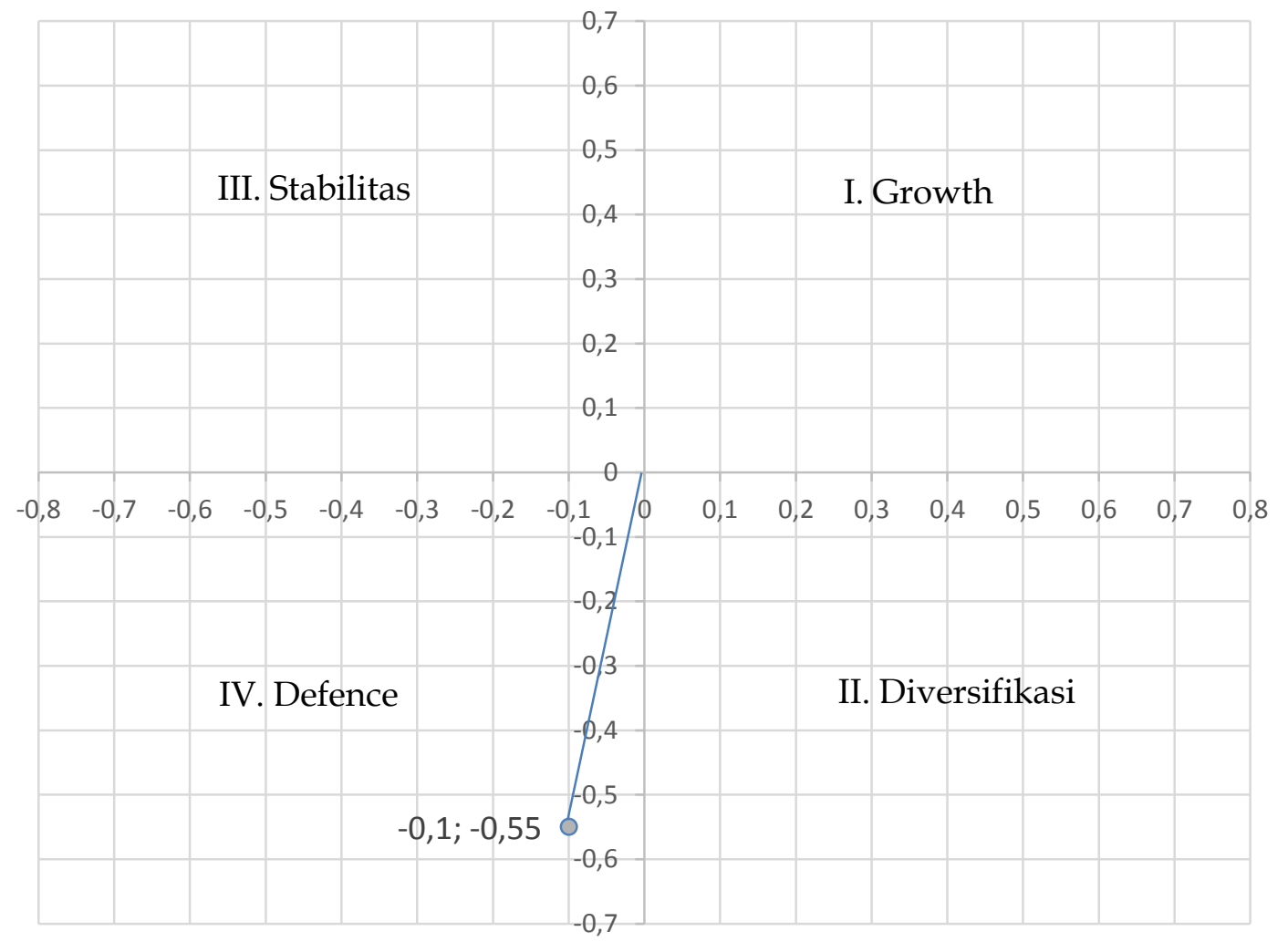

Berdasarkan kuadran diatas terlihat bahwa posisi keadaan dari desa wisata osing berdasarkan analisis faktor IFAS dan EFAS berada dalam kuadran IV. Kuadran tersebut mencerminkan suatu kondisi yang perlu untuk dilakukan dalam pemulihan terhadap pandemi Covid-19. Posisi pada kuadran pada analisis SWOT merepresentasikan suatu tingkat perlakuan ataupun perumusan strategi yang digunakan, baik untuk pengembangan, peningkatan ataupun pertahanan. Selanjutnya akan disajikan bentuk strategi yang dirumuskan dalam Pengembangan Desa Wisata Adat Osing dalam Upaya Pemulihan Ekonomi Pada Masa Pandemi Covid-19

Strategi Strenght Opportunity (SO) yang dihasilkan meliputi meningkatkan kualitas produk olahan serta tetap mempertahankan

inovasi, meningkatkan pelaksanaan eventevent budaya melalui kerja sama baik bersama perguruan tinggi maupun pemerintah daerah serta mempertahankan lokalitas dan khasanah budaya maupun adat Desa Kemiren, serta membuka ruang bagi digitalisasi desa.

Sedangkan Strategi Weakneses Opportunity (WO) meliputi meningkatkan kualitas SDM dengan memberikan pelatihan dan pendampingan berkaitan dengan produksi serta manajemen usaha, ,meningkatkan pemasaran Desa Wisata Adat Osing melalui berbagai macam media baik secara offline dan online, menjalin kerja sama dengan berbagai stakeholder terutama pemerintah daerah dalam peningkatan saluran pemasaran produk baik offline maupun online serta meningkatkan akses pembiayaan bunga 
rendah melalui lembaga keuangan serta pemanfaatan bantuan pemerintah di era new normal pandemi Covid-19

Strategi strenght Treats (ST) yang dapat dihasilkan meliputi konsisten dalam menjalankan protokol kesehatan era new normal, baik pada kegiatan berproduksi maupun dalam aktivitas pemasaran produk, mengoptimalkan kualitas produk dan layanan yang diberikan kepada wisatawan, meningkatkan kerjasama dengan desa sekitar dalam hal mendukung kepariwisataan wilayah.

Sedangkan strategi Weakneses Treats (WT) yang dapat dihasilkan meliputi pertama mengoptimalkan peningkatan citra dan branding image Desa Wisata Adat Osing agar tetap menjadi pilihan tujuan destinasi wisata era New Normal. Secara garis besar kondisi pandemi Covid-19 membuat seluruh pengelola destinasi wisata maupun pelaku usaha wisata melakukan banyak cara untuk dapat bertahan hidup termasuk juga pada desa wisata adat osing, sehingga diperlukan branding image yang bukan hanya sekedar logo, slogan, tagline atau elemen visual lainnya tetapi juga secara konsisten dalam komunikasi pemasaran maupun penyampaian pelayanan yang diberikan dengan baik seperti pelaksanaan protocol kesehatan yang ketat di kawasan desa wisata adat osing dengan tujuan kebersihan, kesehatan, keselamatan dan kelestarian. Maka dari itu penting untuk melakukan branding image agar menciptakan inovasi dan kreativitas dalam upaya untuk meningkatkan kualitas destinasi wisata di era new normal. Kedua, meningkatkan kapasitas SDM pelaku pariwisata dalam penggunaan sarana teknologi digital dalam menunjang kepariwisataan pada masa pandemi Covid19. Sumber daya manusia memegang peranan yang penting pada pengembangan pariwisata, dengan adanya penggunaan teknologi pelaku pariwisata dituntut untuk memiliki pengetahuan dan keterampilan yang mumpuni untuk menjawab segala kebutuhan desa wisata di masa pandemi. Oleh karena itu dibutuhkan kegiatan pendampingan yang berkelanjutan serta,diadakannya pendidikan dan pelatihan bagi pelaku wisata di desa wisata osing agar mampu mengoperasikan teknologi digital yang ada dan mengaplikasikannya secara tepat. Karena pelaku usaha wisata menjadi ujung tombak keberhasilan pengembangan desa wisata yang perlu untuk tetap diberdayakan demi meningkatkan jumlah kunjungan wisatawan. Ketiga merubah tren pariwisata menjadi wisata berbasis teknologi dalam hal pemasaran produk dan pengelolaan kepariwisataan. Tingginya kecintaan masyarakat desa wisata osing terhadap seni dan budaya menjadikan daya Tarik tersendiri bagi wisatawan untuk berkunjung selain menikmati keindahan alamnya. Oleh karena itu dibutuhkan inovasi tren pengelolaan desa wisata yang dapat dimulai dengan pengembangan wisata virtual, yaitu kegiatan wisata yang mengajak pengunjung berkeliling ke sejumlah objek wisata di desa wisata osing tanpa harus datang langsung ke lokasi dan berada diantara kerumunan orang dengan memanfaatkan perantara teknologi saat ini, kemudian meningkatkan peranan platform media sosial untuk membantu mempromosikan destinasi wisata desa adat osing dan produk-produk yang dihasilkan dengan membuat spot-spot wisata yang menarik untuk berswafoto, menyiapkan akses bagi wisatawan yang berkeinginan untuk berkunjung langsung ke lokasi desa wisata dengan memesan tiket perjalanan, memilih transportasi, menentukan akomodasi, memesan produk olahan warga setempat hinga mencari informasi tentang desa wisata adat osing melalui smartphone. Memperbaharui akan setiap informasi kondisi yang terjadi pada desa wisata osing juga perlu dilakukan melalui media sosia yang telah dimiliki seperti instagram dan 
facebook yang sudah ada, agar dapat membantu wisatawan untuk mengetahui keadaan disana. Serta keempat menjalin kerja sama dengan pihak swasta maupun pemerintah daerah dalam meneyediakan sarana dan prasarana penunjang aktivitas pariwisata era pandemi Covid-19. Sektor pariwisata tentunya tidak pernah bisa berjalan sendiri, dibutuhkan kolaborasi antar sector agar keberlanjutan dari usaha pengembangan dapat tetap berjalan. Persoalan yang dihadapi dalam pengembangan desa wisata osing ini belum optimalnya sarana prasarana pendukung pada masa pandemic Covid-19 yaitu belum adanya standard operational procedur (SOP) tentang penerapan protokol kesehatan ,belum tesedianya tempat khusus karantina bagi wisatawan yang berkunjung apabila terindikasi Covid-19, kemudian dibutuhkan komunikasi dengan Dinas Kesehatan Daerah apabila terdapat pengunjung yang terpapar virus, belum adanya pula standar pelayanan ketika ada kasus yang berkaitan dengan pandemi yang berada di desa wisata osing. Berdasarkan hal tersebut penting kiranya dilakukan kerja sama dengan pihak swasta maupun pemerintah daerah dalam meneyediakan sarana dan prasarana penunjang aktivitas pada masa pandemi.

Berdasarkan pengolahan data dan digambarkan diatas, analisis terhadap Desa Wisata Adat Osing berada pada kuadran ke IV yaitu Strategi : defence oriented strategy (Strategi bertahan), dimana pada kuadran ini bertujuan untuk mengurangi kelemahan (weakneses) internal dengan menghindari ancaman (treats) eksternal. Strategi yang dapat dilakukan yaitu 1)Mengoptimalkan peningkatan citra dan branding image Desa Wisata Adat Osing agar tetap menjadi pilihan tujuan destinasi wisata era New Normal; 2)Meningkatkan kapasitas SDM pelaku pariwisata dalam penggunaan sarana teknologi digital dalam menunjang kepariwisataan masa pandemi Covid-19, 3)Merubah tren pariwisata menjadi wisata berbasis teknologi dalam hal pemasaran produk dan pengelolaan kepariwisataan; dan 4)Menjalin kerja sama dengan pihak swasta maupun pemerintah daerah dalam meneyediakan sarana dan prasarana penujang aktivitas pariwisata masa pandemi Covid-19.

\section{PENUTUP}

Terdapat empat strategi yang dihasilkan untuk mengatasi persoalan pengembangan desa wisata osing dalam pemulihan ekonomi pada masa pandemi yang meliputi, (1) Mengoptimalkan peningkatan citra dan branding image Desa Wisata Adat Osing agar tetap menjadi pilihan tujuan destinasi wisata era New Normal. Untuk meningkatkan kualitas destinasi desa wisata adat osing di mata wisatawan domestik dan mancanegara. (2) Meningkatkan kapasitas SDM pelaku pariwisata dalam penggunaan sarana teknologi digital dalam menunjang kepariwisataan masa pandemi Covid-19. Untuk menjawab kebutuhan desa wisata osing di masa pandemi dengan penggunaan digitalisasi. (3) Merubah tren pariwisata menjadi wisata berbasis teknologi dalam hal pemasaran produk dan pengelolaan kepariwisataan. Untuk mengidupkan desa wisata osing melalui inovasi produk yang lebih disukai konsumen dengan model pengemasan yang menarik dan kekinian. (4) Menjalin kerja sama dengan pihak swasta maupun pemerintah daerah dalam meneyediakan sarana dan prasarana penujang aktivitas pariwisata masa pandemi Covid-19. Untuk menjaga kenyamanan para pengunjung dalam menikmati desa wisata osing di masa pandemi dengan aman.

\section{DAFTAR PUSTAKA}

Baswir,R.1995.Tiada Ekonomi Kerakyatan Tanpa Keadulatan Rakyat, dalam Baswir.1997.Agenda Ekonomi Kerakyatan, Pustaka Pelajar, Yogyakarta. 
Baker,G.P.Jensen,M.C., \& Murphy,K.J (1988). Compensation and Incenives: Practice vs Theory. The Journal Of Finance,43(3),593-616

Creswell, John W. (2009). Research Design Pendekatan Penelitian Kualitatif, Kuantitatif, dan Mixed. Yogyakarta: Pustaka Pelajar. Penterjemah Achmad Fawaid.

Chusmeru dan Agoeng Noegroho. (2010). "Potensi Ketengger Sebagai Desa Wisata di Kecamatan Baturraden, Kabupaten Banyumas". Analisis Pariwisata Vol. 10, No. 1, 2010: 16-23.

Dalimunthe. 2007. “Partisipasi Masyarakat dalam Pengembangan Potensi Wisata Bahari Pantai Cermin Kabupaten Serdang Bedagai". Tesis.Sedang Bedagai.
Dewi,M.H.U.2004. Dampak Ekonomi Pariwisata terhadap Kesejahteraan Masyarakat Lokal di Tiga Desa Kawasan Wisata Lovina. Denpasar: Lembaga Penelitian, Universitas Udayana

Hadiwijoyo. (2012). Perencanaan Pariwisata Perdesaan Berbasis Masyarakat. Yogyakarta: Graha Ilmu.

O.S. Prijono, O.S. \& A.M.W. Pranarka. (1996). Pemberdayaan: Konsep, Kebijakan, dan Implementasi. Jakarta: CSIS

Wrihatnolo dan Dwidjowijoto.(2007). Manajemen Pemberdayaan. Jakarta: Elex Media Komputindo.

Undang -undang Nomor 10 Tahun 2009 tentang Kepariwisataan 